\title{
Tinjauan Yuridis Terhadap Notaris Yang Dinyatakan Pailit Ditinjau Berdasarkan Undang-Undang Jabatan Notaris
}

\author{
Aga Waskitha Wiryawan \\ Magister Kenotariatan Fakultas Hukum Universitas Islam Indonesia \\ Jln. Cik Di Tiro No. 1, Yogyakarta, 55223 \\ aga.waskita@yahoo.com
}

\begin{abstract}
This research discusses the Juridical Review of Notaries who have been Declared as Bankrupt under the Law of Notary Office. The problems formulated in this study are 1) What are the factors to declare a Notary as bankrupt based on the Law on Notary Office? 2) What is the legal consequence of a Notary declared bankrupt based on the Law on Notary Office? This is a normative study with statutory approach and qualitative analysis methods. The results of this research conclude that the factors to declare a Notary as bankrupt by the court, among others, due to the inability to pay compensation to creditors outside of his / her position as a notary, namely as someone with another business that does not violate his / her position. Furthermore, the legal consequence of the bankruptcy is being dishonorably discharged by the Ministry of Law and Human Rights, which violates the dignity of the Notary in accordance with the rules in the Notary Code of Ethics, hence it is considered a disgraceful act and humiliates the Notary's dignity and position.
\end{abstract}

Key Words: Bankrupt; Law on Notary Office; notary

\begin{abstract}
Abstrak
Penelitian ini membahas Tinjauan Yuridis Terhadap Notaris yang Dinyatakan Pailit Ditinjau Berdasarkan Undang-Undang Jabatan Notaris. Masalah yang dirumuskan dalam penelitian ini adalah 1) Apa faktor-faktor yang menyebutkan Notaris dinyatakan pailit berdasarkan Undang-Undang Jabatan Notaris? 2) Apa akibat hukum Notaris yang dinyatakan pailit berdasarkan Undang-Undang Jabatan Notaris? Penelitian ini bersifat normatif dengan pendekatan perundang-undangan (statute approach) dan metode analisis kualitatif. Hasil dari penelitian ini menyimpulkan bahwa faktor Notaris dapat dinyatakan pailit oleh pengadilan antara lain karena tidak sanggup membayar ganti rugi kepada kreditur diluar jabatannya sebagai Notaris yaitu sebagai seseorang dengan usaha lain yang tidak melanggar jabatannya. Selanjutnya akibat hukum dari kepailitan tersebut adalah Notaris diberhentikan secara tidak hormat oleh Kementerian Hukum dan Hak Asasi Manusia, yang melanggar harkat dan martabat Notaris sesuai dengan aturan dalam kode Etik Notaris, sehingga dianggap sebagai perbuatan yang tercela dan mempermalukan martabat Notaris serta jabatannya.
\end{abstract}

Kata-kata Kunci: Notaris; pailit; undang-undang jabatan notaris 


\section{Pendahuluan}

Notaris sebagai jabatan sesuai dengan Pasal 1 ayat (1) Undang-Undang Nomor 2 Tahun 2014 tentang Perubahan Atas Undang-Undang Nomor 30 Tahun 2004 tentang Jabatan Notaris (selanjutnya disebut UUJN) yaitu pejabat umum yang berwenang untuk membuat akta autentik dan memiliki kewenangan lainnya sebagaimana dimaksud dalam undang-undang ini atau berdasarkan undang-undang lainnya. Notaris sebagai pejabat umum dituntut untuk selalu bertindak secara profesional dalam menjalankan tugas dan kewenangannya sesuai dengan standar jabatan yang diamanatkan pada UUJN. Untuk menjaga kadar profesional dan integritas moral dari Notaris, maka perlu adanya suatu organisasi yang solid yang mampu membawa dan menjaga para anggotanya untuk selalu bersikap profesionalisme dalam menjalankan tugas dan jabatannya, sehingga keluhuran martabat Jabatan Notaris senantiasa dijaga dengan baik. Hal ini telah diamanatkan dalam ketentuan Pasal 82 ayat (1) UUJN yang mewajibkan para Notaris berkumpul pada suatu wadah tunggal.

Seorang Notaris di dalam menjalankan jabatannya juga berkewajiban untuk bekerja secara mandiri, jujur, tidak memihak, dan penuh rasa tanggung jawab serta memberikan pelayanan kepada masyarakat yang memerlukan jasanya dengan sebaik-baiknya (Pasal 16 UUJN). Seorang Notaris bekerja dengan aturan yang telah Negara buat dan dibawah naungan Kementerian Hukum dan HAM untuk membantu memberikan pelayanan kepada masyarakat. Dalam bukunya H.M.N. Purwo Sutjipto memberikan perbedaan prinsip antara pekerjaan seorang Notaris dan menjalankan suatu perusahaan. Notaris dan perusahaan sama-sama melakukan kegiatannya secara terus menerus, terang-terangan, dan dalam kedudukan tertentu, akan tetapi terdapat perbedaan yang sangat prinsip antara pekerjaan Notaris dengan menjalankan suatu perusahaan. Notaris menjalankan pekerjaannya tidak bertujuan untuk memperoleh keuntungan atau laba, ia bekerja atas dasar kualitas pribadinya (keahliannya), meskipun ia memperoleh bayaran atas jasanya, tetapi besarnya telah ditetapkan dalam UUJNP, sehingga Notaris bersangkutan tidak dapat menetapkan sendiri besarnya jasa atas kemauannya sendiri. Notaris juga tidak membuat pembukuan layaknya perusahaan dari jasa yang diterimanya dalam pembuatan akta, sehingga dari pendapat para ahli tersebut diambil suatu kesimpulan bahwa seorang Notaris tidaklah menjalankan suatu perusahaan. ${ }^{1}$

Dalam hal Notaris mengalami kesalahan dalam melakukan tugas dan jabatan atau profesinya yang mengakibatkan pemberhentian, Notaris tidak serta

${ }^{1}$ H.M.N. Purwosutjipto, Pengertian Pokok. Hukum Dagang Indonesia Jilid :; Pengetabuan Dasar Hukum Dagang, Djambatan, Jakarta, 1991, hlm. 15-17. 
merta dijatuhi hukuman pemberhentian tanpa ukuran kesalahan tersebut, ukuran kesalahan tersebut seperti halnya pelanggaran ringan atau berat seperti contoh Notaris cuti tetapi tidak melaporkan pada Majelis Pengawas Notaris. Pasal 17 UUJN mengisyaratkan bahwa seorang Notaris di dalam menjalankan profesi atau jabatannya dituntut harus profesional dan bertanggung jawab, bertanggung jawab disini artinya seorang Notaris harus mempertanggung jawabkan jabatan tersebut termasuk kesalahan yang Notaris terima atau lakukan. Sementara itu Pasal 12 UUJN Notaris tentang diberhentikan dengan tidak hormat dari jabatannya oleh Menteri atas usul Majelis Pengawas Pusat apabila:

1. dinyatakan pailit berdasarkan putusan pengadilan yang telah memperoleh kekuatan hukum tetap;

2. berada di bawah pengampuan secara terus-menerus lebih dari 3 tahun;

3. melakukan perbuatan yang merendahkan kehormatan dan martabat jabatan Notaris; atau

4. melakukan pelanggaran berat terhadap kewajiban dan larangan jabatan.

Selain itu dalam Pasal 12 khususnya huruf a Undang-Undang Jabatan Notaris Nomor 30 Tahun 2004 menyatakan bahwa seorang Notaris atas usul Majelis Pengawas Pusat dapat diberhentikan dengan tidak hormat dari jabatannya karena dinyatakan pailit berdasarkan putusan hakim yang telah berkekuatan hukum tetap. Dalam hal ini perlu digaris bawahi bahwa Notaris diberhentikan dari jabatannya karena dinyatakan pailit. Sanksi yang diberikan di dalam pasal tersebut sangat merugikan bagi Notaris, dengan keputusan pailit tersebut Notaris tidak perlu diberhentikan dari jabatannya dengan tidak hormat.

Pasal 12 huruf a UUJN menyatakan Notaris dapat diberhentikan dengan tidak hormat akibat dinyatakan pailit seperti yang telah dijelaskan diatas. Dalam hal ini menimbulkan pertanyaan, dari sisi mana Notaris dianggap pailit dan apa yang menjadi dasar pemikiran dalam kepailitan itu, dan mengapa didalam praktek dibidang kenotariatan bukan dalam kekayaannya pribadi, Jika pada Pasal 12 UUJN tersebut, timbul suatu pertanyaan apakah Notaris adalah seorang pengusaha, ataukah menjalankan suatu perusahaan sehingga ia dapat dipailitkan. Padahal dalam syarat permohonan pernyataan pailit diajukan kepada Pengadilan Niaga, yang persyaratannya menurut Pasal 2 ayat (1) jo. Pasal 8 ayat (4) UU Kepailitan adalah:

1. Ada dua atau lebih kreditor. Kreditor adalah orang yang mempunyai piutang karena perjanjian atau Undang-Undang yang dapat ditagih di muka pengadilan "Kreditor" di sini mencakup baik kreditor konkuren, kreditor separatis maupun kreditor preferen; 
2. Ada utang yang telah jatuh waktu dan dapat ditagih. Artinya adalah kewajiban untuk membayar utang yang telah jatuh waktu, baik karena telah diperjanjikan, karena percepatan waktu penagihannya sebagaimana diperjanjikan, karena pengenaan sanksi atau denda oleh instansi yang berwenang, maupun karena putusan pengadilan, arbiter, atau majelis arbitrase; dan

3. Kedua hal tersebut (adanya dua atau lebih kreditor dan adanya utang yang telah jatuh tempo dan dapat ditagih) dapat dibuktikan secara sederhana.

Selain itu UU Kepailitan mengenal rehabilitasi, yang berarti mengembalikan keadaan hukum debitor seperti semula sama dengan keadaan sebelum pailit. Notaris diberhentikan secara tidak hormat karena dinyatakan pailit oleh putusan pengadilan yang berkekuatan hukum tetap, seharusnya bahwa adanya rehabilitasi ini secara otomatis kepailitan dianggap berakhir.

Penyebab kepailitan tersebut apakah dari harta Notaris saja, karena tidak ada penjelasan yang spesifik apakah yang dipalitkan tersebut seorang Notaris dalam kapasitasnya sebagai orang pribadi (persoon) atau sebagai pejabat umum. Notaris yang telah di berhentikan dengan dasar pailit apakah dapat diangkat lagi, hal tersebut menimbulkan berbagai pertanyaan yang penulis dapat teliti dengan judul Tinjauan Yuridis terhadap Notaris yang Dinyatakan Pailit Ditinjau Berdasarkan Undang-Undang Jabatan Notaris.

\section{Rumusan Masalah}

Berdasarkan uraian latar belakang di atas tersebut, maka permasalahan dalam penelitian ini adalah: Pertama, apa faktor-faktor terhadap Notaris yang dinyatakan pailit ditinjau berdasarkan Udang-Undang Jabatan Notaris? Kedua, apa akibat hukum Notaris yang dinyatakan pailit ditinjau berdasarkan UndangUndang Jabatan Notaris?

\section{Tujuan Penelitian}

Adapun tujuan dari penelitian ini: Pertama, untuk mengkaji dan menganalisis mengenai faktor-faktor terhadap Notaris yang dinyatakan pailit ditinjau berdasarkan Undang-Undang Jabatan Notaris. Kdedua, untuk mengkaji dan menganalisis mengenai akibat hukum Notaris yang dinyatakan pailit ditinjau berdasarkan Undang-Undang Jabatan Notaris.

\section{Metode Penelitian}

Penelitian ini merupakan penelitian hukum normatif yaitu penelitian yang berdasar pada kepustakaan (library research), yang merupakan hasil tersebut 
didapat dari pustaka atau buku serta literatur. Penelitian hukum normatif menurut Mukti Fajar ND dan Yulianto Ahmad adalah penelitian hukum yang meletakkan hukum sebagai sistem norma. Sistem norma yang dimaksud adalah mengenai asas-asas, norma, kaidah dari peraturan perundang-undangan, putusan pengadilan, perjanjian serta doktrin (ajaran). ${ }^{2}$

Pendekatan ini digunakan untuk mengkaji secara mendalam tentang proses dan akibat hukum Terhadap Notaris yang dinyatakan Pailit dan penerapan dalam praktek di lapangan mengenai Notaris yang dinyatakan Pailit.

\section{Hasil Penelitian dan Pembahasan}

\section{Faktor-faktor Notaris Dinyatakan Pailit Ditinjau Berdasarkan Undang-Undang Jabatan Notaris}

Pailit adalah suatu keadaan dimana debitur sudah tidak mampu lagi untuk melakukan pembayaran terhadap hutang dari para krediturnya. Keadaan ini tidak dapat membayar ini dapat disebakan karena mengalami kesulitan kondisi dalam keuangan. Dalam Pasal 1 Undang-Undang Nomor 37 Tahun 2004 tentang Kepailitan dan Penundaan Kewajiban Pembayaran Utang (UU Kepailitan) menjelaskan bahwa kepailitan ialah sita umum atas semua kekayaan debitur pailit yang pengurusan dan pemberesannya dilakukan oleh kurator dibawah pengawasan hakim pengawas sebagaimana diatur dalam undang-undang ini.

Pasal 12 huruf a UUJN, yaitu Notaris dapat diberhentikan secara tidak hormat karena telah dinyatakan pailit berdasarkan putusan pengadilan yang telah memperoleh kekuatan hukum tetap. Dalam putusan pailit dari pengadilan yang telah berkekuatan hukum tetap ini mengakibatkan Notaris diberhentikan secara tidak hormat dan akan kehilangan hak dan kewajibannya sebagai jabatan Notaris, sehingga dapat dikatakan Notaris dianggap tidak cakap dalam menjalankan kewenangannya sebagai pejabat umum, karena Notaris tersebut dinyatakan pailit oleh pengadilan. Apabila Notaris yang dinyatakan pailit oleh pengadilan karena tidak sanggup membayar ganti rugi kepada kreditur, Notaris berhutang kepada kreditur diluar jabatannya sebagai Notaris, yaitu sebagai seorang dengan usaha lain yang tanpa melanggar jabatannya, dan karena ketidaksanggupan Notaris tersebut dalam membayar ganti rugi kepada kreditur maka Notaris tersebut dinyatakan pailit oleh pengadilan dan akibat dari kepailitan tersebut adalah juga sebagai jabatan Notaris diberhentikan secara tidak hormat oleh Kementerian Hukum dan Hak Asasi Manusia.

2 Mukti Fajar ND dan Yulianto Achmad, Dualisme Penelitian Hukum Normatif dan Hukum Empiris, Pustaka Pelajar, Yogyakarta, 2010, hlm. 34. 
Menurut pendapat Notaris Enarwanto ${ }^{3}$ faktor pailit dapat dikategorikan sebagai hal yang mempengaruhi jati diri seorang pejabat umum yaitu Notaris, meskipun yang dinyatakan pailit usaha yang lain tetapi hal tersebut dapat mengakibatkan seseorang yang merangkap Notaris terkena imbasnya, faktor umum Notaris terkena pailit karena Notaris tersebut secara pribadi telah habis harta untuk membayar hutang atau ganti rugi kepada pihak yang telah melaporkan kegagalan seseorang pengusaha, dan tidak dapat membayar hutang tersebut.

Dalam pernyataan pailit yang telah dijatuhkan oleh hakim, seseorang dapat melakukan rehabilitasi yaitu dalam Pasal 215 Undang-Undang Nomor 37 Tahun 2004 tentang Kepailitan Dan Penundaan Kewajiban Pembayaran Utang di jelaskan bahwa setelah berakhirnya kepailitan sebagaimana dimakhsud dalam Pasal 166, Pasal 202, dan Pasal 207 UU Kepailitan, maka debitur atau ahli warisnya berhak mengajukan permohonan rehabilitasi kepada pengadilan yang telah mengucapkan putusan pernyataan pailit. Dalam Pasal 216 menjelaskan bahwa permohonan rehabilitasi baik debitur maupun ahli warisnya tidak akan dikabulkan, kecuali apabila pada surat permohonan tersebut dilampirkan bukti yang menyatakan bahwa semua kreditur yang diakui sudah memperoleh pembayaran secara bersih.

Berdasarkan dari penjelasan pasal tersebut diatas dapat dilihat Notaris yang meminta untuk direhabilitasi untuk mengembalikan nama baik mereka atas persetujuan atau sepengetahuan dari kreditur karena kreditur memberikan lampiran bukti yang menyatakan bahwa semua kreditur yang diakui sudah memperoleh pembayaran secara bersih tanpa adanya gugatan lagi dari kreditur sehingga debitur berhak untuk mengajukan rehabilitasi guna untuk memperbaiki nama baiknya kembali. Dalam hal Notaris yang telah menyelesaikan proses pailit dan telah melakukan rehabilitasi untuk memperbaiki nama baiknya sebagai pejabat umum sampai sekarang masih belum jelas apakah Notaris yang telah menyelesaikan proses pailit dan telah melakukan rehabilitasi untuk memperbaiki nama baiknya dapat mengajukan pengangkatan kembali ke Kementrian Hukum Dan Ham atau tidak, karena tidak ada ketentuan yang mengatur mengenai permasalahan tersebut secara rinci.

Sedangkan menurut pendapat Notaris $X^{4}$ faktor pailit dapat dikategorikan sebagai kesalahan yang dilakukan Notaris karena Notaris melakukan wanprestasi dan tidak dapat membayar kewajibannya kepada seseorang yang dirugikan, Notaris tersebut digugat oleh pihak yang dirugikan untuk memberikan ganti rugi

\footnotetext{
3 Wawancara dengan Notaris Enarwanto, pada tanggal 2 Desember 2019.

${ }^{4}$ Wawancara dengan Notaris X, pada tanggal 5 Desember 2019.
} 
terhadap kesalahannya yang menyebabkan kewajiban seorang Notaris tidak terpenuhi dan dalam pembuatan akta menjadi batal demi hukum yang dapat menimbulkan kerugian bagi para pihak, dan menjadikan nilai yang dirugikan tidak dapat dibayarkan oleh Notaris berdasarkan gugatan para pihak hingga putusan pengadilan tersebut.

Sedangkan Notaris yang tidak dapat menjalankan kewajibannya untuk memberi ganti rugi karena tidak memiliki cukup harta dan tidak mampu lagi untuk memberikan ganti kerugian kepada pihak yang dirugikan, maka atas penggugat atau Notaris bersangkutan dapat mengajukan pernyataan pailit, dan ketentuan sebagaimana dimaksud dalam Pasal 12 huruf a UUJN tersebut dapat dijalankan, dengan usul Majelis Pengawas yang dapat diberhentikan dari jabatannya. Berbeda sebagai seseorang pribadi tidak menyangkutkan jabatan Notaris tersebut dipailitkan maka akibat hukum yang timbul adalah sebagaimana diatur di dalam UUK Nomor 37 Tahun 2004, dan seorang tersebut kehilangan hak untuk melakukan perbuatan hukum dalam bidang harta, dalam hal ini ketentuan sebagaimana diatur dalam Pasal 12 UUJN tidak dapat dijalankan, sebab kepailitan terhadap orang pribadi pengaturannya berada pada lingkup undang-undang kepalitan, sedangkan terhadap Notaris yang pailit hanya diatur di dalam UUJN karena Notaris bukan perusahaan, di sisi lain kepalitan itu timbul karena adanya utang piutang yang timbul berdasarkan perjanjian, apabila seharusnya sebagai pribadi yang dinyatakan pailit tidak dapat diberhentikan dari jabatannya sebagai Notaris.

Seperti dalam buku Habib Adjie yang berjudul "Sanksi Perdata Dan Administratif terhadap Notaris Sebagai Pejabat Publik", juga berpendapat sama, bahwa yang dimaksud Notaris pailit adalah jika Notaris tersebut digugat untuk memberikan ganti rugi akibat kesalahannya yang menyebabkan suatu akta menjadi kehilangan kekuatan pembuktian sebagai akta otentik, atau suatu akta yang dibuat oleh atau dihadapannya menjadi batal demi hukum sehingga menimbulkan kerugian bagi para pihak, dan ternyata nilai kerugian yang dituntut begitu besar, sehingga seluruh harta Notaris tersebut tidak mencukupi untuk menggantinya, dinyatakan pailit berdasarkan keputusan pengadilan yang berkekuatan hukum tetap. ${ }^{5}$

Demikian Habib Adjie menyatakan bahwa suatu hal yang tidak logis jika Notaris sebagai jabatan resmi dikenakan pengaturan Kepailitan dan Penundaan Kewajiban Pembayaran Utang, dan oleh karena itu ketentuan yang tersebut dalam Undang-Undang Nomor 37 Tahun 2004 menurut Habib Adjie tidak

${ }^{5}$ Habib Adjie, Sanksi Perdata dan Administratif Terbadap Notaris sebagai Pejabat Publik, Refika Aditama. Bandung, 2008, hlm. 64. 
berlaku untuk Notaris untuk diterapkan pada Pasal 12 huruf a UUJN. Dalam hal ini faktor pailit tidak karena seorang menjabat Notaris tetapi faktor usaha lain yang dijalankan Notaris tetapi tidak melanggar ketentuan jabatan Notaris.

Menurut pendapat narasumber Hakim DS6 bahwa, jabatan seorang Notaris dapat dipailitkan. Notaris yang dipailitkan sebagaimana dimaksud dalam Pasal 12 huruf a UUJN Nomor 30 Tahun 2004 adalah personnya atau orangnya sebagai harta kekayaan yang dimiliki perorangnya. Seorang Notaris yang dinyatakan pailit mempunyai kedudukan sebagai subjek hukum, bukan dalam nama jabatan, karena yang dinyatakan subjek hukum dalam kepailitan yaitu subyek yang merupakan orang dan badan hukum, sedangkan jabatan Notaris bukan merupakan badan hukum, ketentuan dalam Pasal 12 huruf a UUJN berlaku pribadi itu sendiri.

Pemberhentian Notaris karena dinyatakan pailit sebagaimana dimaksud dalam Pasal 12 huruf a UUJN merupakan sanksi administratif dan perdata, Seorang Notaris yang karena kesalahan atau melakukan pelanggaran sebagaimana dimaksud dalam Pasal 84 UUJN yaitu merupakan ketentuan sanksi, yang mengakibatkan kerugian bagi pihak atas perilaku seorang Notaris, sehingga mewajibkan Notaris tersebut harus memberi ganti kerugian, dengan demikian para pihak yang dirugikan dapat menggugat secara perdata. Dalam Pasal 12 UUJN mengenai Notaris yang dipailitkan faktor tersebut hanya mengenai seorang pribadi Notaris tidak dapat melakukan pembayaran ganti rugi, selanjutnya dalam sanksi atas pailit Notaris tidak ada penjelasan yang spesifik mengenai hal tersebut, dan peraturan pelaksananya belum jelas ukuran pailit Notaris.

Pembahasan dari hasil penelitian diatas dapat dianalisis, bahwa dalam kepailitan Notaris yang tertuang dalam Pasal 12 huruf a UUJN menyatakan bahwa seorang Notaris atas usul majelis pengawas pusat dapat diberhentikan dengan tidak hormat dari jabatannya karena dinyatakan pailit berdasarkan putusan hakim yang telah berkekuatan hukum tetap. Faktor yang mengakibatkan pailit karena Notaris merupakan seorang pribadi dibalik baju jabatan Notaris, seorang pribadi tersebut tidak dapat menjalankan pekerjaannya sesuai amanah undang-undang atau tidak dapat menjalankan jabatannya karena hal tertentu, salah satu contoh akta yang dibuat Notaris terkena masalah dan kerugian yang diterima para pihak melebihi kemampuan Notaris tersebut hingga akhirnya para pihak menggugat Notaris untuk dipailitkan, contoh yang kedua ialah seorang Notaris mempunyai perusahaan lain yang karena kerugian tersebut seorang pribadi Notaris tersebut di pailitkan atas dasar masalah perusahaan tersebut, sebagai Jabatan Notaris yang melekat pada dirinya terkena imbas dari pailit

${ }^{6}$ Wawancara dengan Hakim DS, pada tanggal 7 Desember 2019. 
tersebut. Hal ini dapat terjadi dengan alasan faktor-faktor pribadi, bukan karena faktor jabatan Notaris itu sendiri, Undang-Undang Jabatan Notaris yang menjelaskan tentang peraturan pelaksananya tidak spesifik, maka dalam hal ini Notaris dapat dirugikan secara jabatannya

\section{Akibat Hukum Notaris yang Dinyatakan Pailit Ditinjau Berdasarkan Undang- Undang Jabatan Notaris}

Akibat hukum dari kepailitan ini adalah Notaris kehilangan hak untuk menguasai dan mengurus harta kekayaanya (harta pribadi) yang termasuk di dalam harta pailit tersebut, sejak pernyataan putusan pailit dilakukan. Akibat hukum dari kepailitan yang dialami oleh Notaris ini telah diatur di dalam Pasal 12 huruf a UUJN atau dapat saja pada Pasal 24 ayat (1) Undang-Undang Nomor 37 Tahun 2004 tentang Kepailitan dan Penundaan Kewajiban Pembayaran Utang.

Selanjutnya akibat hukum dari Notaris yang telah dinyatakan pailit oleh pengadilan seperti yang telah diatur di dalam Pasal 12 huruf a Undang-Undang Nomor 2 Tahun 2014 tentang Perubahan Atas Undang-Undang Nomor 30 Tahun 2004 tentang Jabatan Notaris, secara yuridis berbeda dengan ketentuan yang diatur di dalam Undang-Undang Nomor 37 Tahun 2004 tentang kepailitan akibat hukum kepailitan di dalam undang-undang tersebut secara spesifik tidaklah seperti yang diatur di dalam undang-undang jabatan Notaris yang dimana sampai dapat memberhentikan seseorang dari jabatannya sebagai Notaris. Notaris hanya tidak cakap dalam mengurus harta kekayaannya sehingga hak-hak lain dari Notaris tetap cakap dalam melakukan perbuatan hukum yang lain atas pekerjaan pembuatan akta atau kewenangan dalam pembuatan surat tertulis lainnya. Hak-hak lain disini ialah Notaris yang telah dinyatakan pailit seharusnya berhak dan cakap untuk menjalankan kewenangannya sebagai pejabat, disisi lain menurut undang-undang jabatan Notaris mengatur bahwa Notaris yang telah dinyatakan pailit maka akan diberhentikan secara tidak hormat dari jabatannya, sehingga dapat dikatakan bahwa Notaris dianggap telah tidak cakap dalam menjalankan kewenangannya sebagai seorang pejabat umum yaitu Notaris.

Menurut pendapat Notaris Enarwanto, ${ }^{7}$ tentang akibat hukum Notaris yang telah dinyatakan pailit, tidak hanya kerugian tidak bisa membayar kerugian para pihak saja tetapi Notaris sebagai pejabat akan hilang kewenangan dan hak hak Notaris tersebut. Hal ini yang telah diatur dalam Pasal 12 huruf a UUJN yaitu Pasal 12 huruf a Undang-Undang Jabatan Notaris menyatakan bahwa seorang Notaris atas usul majelis pengawas pusat dapat diberhentikan dengan tidak

\footnotetext{
7 Wawancara dengan Notaris Enarwanto.
} 
hormat dari jabatannya karena dinyatakan pailit berdasarkan putusan hakim yang telah berkekuatan hukum tetap. Di berhentikan tidak hormat, jelas tidak hormat merupakan pelanggar terberat dalam sanksi di Undang-Undang Jabatan Notaris.

Pasal 1 angka 1 Undang-Undang Kepailitan menyebutkan, bahwa yang dimaksud debitor adalah orang yang mempunyai utang karena perjanjian atau undang-undang, yang dapat ditagih di muka pengadilan, selanjutnya pada Pasal 1 angka 6 Undang-Undang Kepailitan disebutkan bahwa utang adalah kewajiban yang dinyatakan dalam jumlah uang, baik dalam mata uang Indonesia maupun mata uang asing, baik secara langsung maupun yang akan timbul dikemudian hari, yang timbul karena perjanjian atau Undang-undang dan yang wajib dipenuhi oleh debitur, dan bila tidak dipenuhi memberi hak kepada kreditur untuk mendapat pemenuhannya dari harta kekayaan debitur. Dalam hal ini bahwa untuk dapat dinyatakan pailit harus dipenuhi beberapa unsur yaitu adanya utang yang tidak cakap untuk membayar dan hal ini menimbulkan perjanjian yang dilakukan antara para pihak.

Menurut Pendapat Notaris $X$ akibat hukum terhadap pailit yang dilakukan oleh Notaris salah satunya terhadap akta yang dibuat oleh atau dihadapan Notaris tersebut yang menjadi kehilangan otentiknya, yang mengakibatkan para pihak yang dirugikan dan dapat menuntut Notaris tersebut secara perdata, dengan menuntut Notaris tersebut untuk memberi ganti kerugian atas kelalaian Notaris tersebut melalui pengadilan Negeri.

Akibat dari pailit, Notaris melakukan pelanggar yang UUJN telah tulis yaitu, Melanggar ketentuan Pasal 16 ayat (1) huruf i, yaitu tidak membacakan akta dihadapan penghadap dengan dihadiri paling sedikit oleh 2 orang saksi, dan ditandatangani pada saat itu juga oleh para penghadap, saksi-saksi dan Notaris. Melanggar ketentuan Pasal 16 ayat (7) dan ayat (8), yaitu jika Notaris pada akhir akta tidak mencantumkan kalimat bahwa para penghadap atas permintaannya tidak dibacakan akta, karena penghadap sudah mengerti atau telah membaca sendiri, serta telah mengetahui dan memahami apa yang termuat dalam akta tersebut. Melanggar ketentuan Pasal 41, yang berkaitan atau berhubungan dengan Pasal 39 dan 40 UUJN.

Menurut Pendapat Hakim DS, akibat hukum Notaris yang pailit pada Pasal 9 UUJN dan Pasal 12 huruf a UUJN, bahwa Notaris diberhentikan sementara dari jabatannya karena dalam proses pailit atau penundaan kewajiban pembayaran utang" (Pasal 9 ayat (1) huruf a UUJN). Notaris diberhentikan dengan tidak hormat dari jabatannya oleh Menteri atas usul Majelis Pengawas Pusat apabila 
dinyatakan pailit berdasarkan putusan pengadilan yang telah memperoleh kekuatan hukum tetap" (Pasal 12 ayat (1) huruf a UUJN).

Hal ini kurang spesifik atas perihal Notaris yang dinyatakan pailit tersebut, Notaris tersebut dipailitkan dalam jabatannya, atau sebagai orang pribadi. Berbeda dengan Undang-Undang Nomor 37 Tahun 2004 Undang-Undang Kepailitan telah memberikan penjelasan secara terperinci mengenai pihak-pihak yang dapat dinyatakan pailit, dan apa akibat-akibat hukum dari keputusan pailit tersebut, dan dari pada itu dalam UU Kepailitan bahwa akibat dari kepailitan yang di lakukan seseorang tidak menyebabkan seseorang dapat kehilangan hak untuk menjalankan jabatannya.

Hal ini seseorang yang dinyatakan pailit menjadi tidak cakap untuk melakukan perbuatan hukum. Bahwa dapat disimpulkan akibat hukum yang terjadi, bahwa Notaris yang dinyatakan pailit tidak dapat lagi menjadi Notaris, yang berwenang seperti hal nya diatur pada Pasal 15 UUJN bahwa Notaris tidak dapat:

1. membuat akta autentik mengenai semua perbuatan, perjanjian, dan penetapan yang diharuskan oleh peraturan perundang-undangan dan/atau yang dikehendaki oleh yang berkepentingan untuk dinyatakan dalam akta autentik, menjamin kepastian tanggal pembuatan akta, menyimpan akta, memberikan grosse, salinan dan kutipan akta;

2. mengesahkan tanda tangan dan menetapkan kepastian tanggal surat di bawah tangan dengan mendaftar dalam buku khusus;

3. membukukan surat di bawah tangan dengan mendaftar dalam buku khusus;

4. membuat kopi dari asli surat di bawah tangan berupa salinan yang memuat uraian sebagaimana ditulis dan digambarkan dalam surat yang bersangkutan;

5. melakukan pengesahan kecocokan fotokopi dengan surat aslinya;

6. memberikan penyuluhan hukum sehubungan dengan pembuatan akta;

7. membuat akta yang berkaitan dengan pertanahan;

8. membuat akta risalah lelang.

Notaris mempunyai fungsi dalam pembuatan akta diranah hukum privat, dan akta Notaris merupakan akta tertutup atau bersifat privat hanya para pihak, saksi dan orang yang berkepentingan yang dapat mengetahui isi akta, hal ini dijelaskan pada Pasal 54 ayat (1) UUJN yaitu Notaris hanya dapat memberikan, memperlihatkan, atau memberitahukan isi Akta, Grosse Akta, Salinan Akta atau Kutipan Akta, kepada orang yang berkepentingan langsung pada Akta, ahli waris, atau orang yang memperoleh hak, kecuali ditentukan lain oleh peraturan perundang-undangan. 
Semua kewenangan Notaris di atas adalah merupakan perbuatan hukum. Perbuatan hukum adalah perbuatan yang memiliki akibat hukum, bahwa kewenangan Notaris merupakan perbuatan hukum yang memiliki akibat-akibat hukum. Bahwa dapat diketahui bahwa seorang Notaris yang dinyatakan pailit tidak bisa menjadi Notaris karena ia tidak dapat melaksanakan kewenangannya pada saat ia berada dalam keadaan tidak cakap, bahwa dapat dijelaskan Notaris yang pailit otomatis akan diberhentikan dari jabatannya, hal ini diatur pada Pasal 12 UUJN tentang pemberhentian sementara atau pemberhentian tidak hormat dikarenakan kepailitan pada Notaris.

\section{Penutup}

Dari penelitian di atas dapat disimpulkan sebagai berikut: Pertama, Notaris yang dinyatakan pailit berdasarkan UUJN, khususnya tertuang pada Pasal 9 UUJN dan Pasal 12 huruf, dapat diberhentikan sementara dari jabatannya karena dalam proses pailit atau penundaan kewajiban pembayaran utang (Pasal 9 ayat (1) huruf a UUJN). Notaris diberhentikan dengan tidak hormat dari jabatannya oleh Menteri atas usul Majelis Pengawas Pusat apabila dinyatakan pailit berdasarkan putusan pengadilan yang telah memperoleh kekuatan hukum tetap (Pasal 12 ayat (1) huruf a UUJN). Bahwa Notaris yang dinyatakan pailit oleh pengadilan karena tidak sanggup membayar ganti rugi kepada kreditur, Notaris berhutang kepada kreditur diluar jabatannya sebagai Notaris yaitu sebagai seorang dengan usaha lain yang tidak melanggar jabatannya maupun UUJN, dan karena ketidaksanggupan Notaris tersebut dalam membayar ganti rugi kepada kreditur maka Notaris tersebut dinyatakan pailit oleh pengadilan. Kedua, akibat hukum dari kepailitan tersebut adalah Notaris diberhentikan secara tidak hormat oleh Kementerian Hukum dan Hak Asasi Manusia, tidak hanya itu bahwa hal pemberhentian tidak hormat adalah hal yang melanggar harkat dan martabat Notaris sesuai dengan aturan dalam kode etik Notaris, sehingga dianggap sebagai perbuatan yang tercela dan mempermalukan martabat Notaris serta jabatannya.

Dalam Penelitian di atas mempunyai saran yang dituangkan oleh penulis sebagai berikut: Pertama, bahwa dalam UUJN perlu dijelaskan secara terperinci mengenai kepailitan Notaris, karena hal ini menyangkut harga diri dan martabat Notaris dalam melaksanakan jabatannya. Kedua, bahwa Notaris harus berhati-hati dalam melakukan jabatannya, karena setiap kewenangan telah diatur sanksisanksi yang harus dihindari. 


\section{Daftar Pustaka}

\section{Buku}

Adjie, Habib, Sanksi Perdata dan Administratif Terhadap Notaris sebagai Pejabat Publik, Refika Aditama, Bandung, 2008.

Hukum Notaris Indonesia: Tafsir Tematik Terhadap UU30 Tahun 2004 tentang Jabatan Notaris, Refika Aditama, Bandung, 2008.

Ali, Chaidir, Yurisprudensi Hukum Dagang, Armico, Bandung, 1982.

Andasasmita, Komar, Notaris Dengan Sejarah, Peranan, Tugas Kewajiban, Rahasia Jabatannya, Sumur, Bandung, 1981.

Anshori, Abdul Ghofur, Lembaga Kenotariatan Indonesia: Perspektif Hukum dan Etika, UII Press, Yogyakarta, 2009.

Asyhadie, Zaeny, Hukum Bisnis Proses dan Pelaksanaannya di Indonesia, RajaGrafindo Persada, Jakarta, 2005. Notaris I, Sumur, Bandung, 1981.

Fatahna, Muchlis, Notaris Bicara Soal Kenegaraan, Watampone Pers, Jakarta, 2008.

Fuady, Munir, Hukum Pailit Dalam Teori dan Praktek, Edisi Revisi, Citra Aditya Bakti, Bandung, 2005.

Kie, Tan Thong, Studi Notariat dan Serba Serbi Praktek Notaris: Buku Kesatu, chtiar Baru Van Hoeve, Jakarta, 2000.

Kohar, A., Notaris dalam Praktek Hukum, Alumni, Bandung, 1983.

Mertokusumo, Soedikno, Hukum Acara Perdata Indonesia, Liberty, Yogyakarta, 1988.

Notodisoerjo, R. Soegondo, Hukum Notariat Di Indonesia Suatu Penjelasan, Raja Grafindo Persada, Jakarta, 1993.

Purwosutjipto, H.M.N., Pengertian Pokok Hukum Dagang Indonesia Jilid I: Pengetahuan Dasar Hukum Dagang, Djambatan, Jakarta, 1991.

Satoto, Sukamto, Pengaturan Eksistensi dan Fungsi Badan Kepegawaian Negara, Offset, Jambi, 2004.

Situmorang, Victor dan Soekarso, Pengantar Hukum Kepailitan di Indonesia, Rineka Cipta, Jakarta, 1994.

Soekanto, Soerjono dan Sri Mamudji, Penelitian Hukum Normatif Suatu Tinjauan Singkat, Raja Grafindo Persada, Jakarta, 2014.

Soesanto, R., Tugas, Kewajiban dan Hak-Hak Notaris Wakil Notaris (sementara), Pradnya Paramita, Jakarta, 1982.

Subekti, R., Kamus Hukum, Pradnya Paramita, Jakarta, 1973.

Sudjito, Ilmu Hukum Holistik Studi Untuk Memahami Kompleksitas dan Pengaturan Pengelolaan Irigasi, Gadjah Mada University Press, Yogyakarta. 2014.

Yani, Ahmad, et. al., Seri Hukum Bisnis Kepailitan, Cetakan Keempat, RajaGrafindo Persada, Jakarta, 2004. 


\section{Hasil Penelitian}

Gozali, Irvan, "Tinjauan Terhadap Notaris Yang Diberhentikan Dari Jabatannya Secara Tidak Hormat Karena Pernyataan Pailit", Tesis, Program Studi Magister Kenotariatan Pascasarjana Universitas Gadjah Mada, Yogyakarta, 2013.

Zainuddin, Irsan, "Akibat Hukum Pernyataan Pailit Terhadap Orang Pribadi Yang Berprofesi Sebagai Notaris", Tesis, Program Studi Magister Kenotariatan Pascasarjana Universitas Diponegoro, Semarang, 2008.

\section{Makalah}

Dja'is, Mochammad dan R.M.J. Koosmargono, "Membaca dan Mengerti HIR", Makalah BP Undip, Semarang, 2008.

Maulano, Martias gelar Iman Radjo, "Pembahasan Hukum; Penjelasan-Penjelasan Istilah-Istilah Hukum Belanda Indonesia untuk Studi dan Praktik", Makalah PD Sumut, Medan, 1969.

Sumardjonno, Maria S.W., "Bahan Kuliah Metodologi Penelitian Ilmu Hukum”, Makalah Universitas Gadjah Mada, Yogyakarta, 2014.

\section{Peraturan Perundang-Undangan}

Kitab Undang-Undang Hukum Perdata.

Undang-Undang Nomor 2 Tahun 2014 tentang Perubahan Atas Undang-Undang Nomor 30 Tahun 2004 Tentang Jabatan Notaris.

Undang-Undang Republik Indonesia Nomor 37 Tahun 2004 tentang Kepailitan Dan Penundaan Kewajiban Pembayaran Utang. 